\title{
Molecular features responsible for the absence of immunoglobulin heavy chain protein synthesis in an $\mathrm{IgH}^{-}$subgroup of multiple myeloma
}

Tomasz Szczepański, Mars B. van 't Veer, Ingrid L. M. Wolvers-Tettero, Anton W. Langerak, and Jacques J. M. van Dongen

This study involved 12 patients with multiple myeloma (MM), in whom malignant plasma cells did not contain immunoglobulin heavy chain $(\mathrm{lgH})$ protein chains. Southern blot analysis revealed monoallelic $\mathrm{J}_{\mathrm{H}}$ gene rearrangements in 10 patients, biallelic rearrangement in 1 patient, and biallelic deletion of the $\mathrm{J}_{\mathrm{H}}$ and $\mathrm{C}_{\mu}$ regions in 1 patient. Heteroduplex polymerase chain reaction analysis enabled the identification and sequencing of 9 clonal $J_{H}$ gene rearrangements. Only 4 of the joinings were complete $V_{H^{-}}(D)-J_{H}$ rearrangements, including 3 in-frame rearrangements with evidence of somatic hypermutation. Five rearrangements con- cerned incomplete $D_{H}-J_{H}$ joinings, mainly associated with deletion of the other allele. Curiously, in at least 1 of these 5 cases the second allele seemed to be in germline configuration, whereas the inframe $V_{k}-J_{k}$ gene rearrangements contained somatic mutations. The configuration of the IGH genes was further investigated by use of $\mathrm{C}_{\mathrm{H}}$ probes. In 5 patients the rearrangements in the $J_{H}$ and $\mathrm{C}_{\mathrm{H}}$ regions were not concordant, probably caused by illegitimate IGH class switch recombination (chromosomal translocations to 14q32.3). These data indicate that in many $\mathrm{IgH}^{-} \mathrm{MM}$ patients illegitimate $/ G H$ class switch rearrangement or illegiti- mate deletion of the functional $V_{H^{-}}\left(D_{H}\right)-J_{H}$ allele are responsible for IgH negativity. For example, the exclusive presence of $D_{H}-J_{H}$ rearrangements in combination with mutated IGK genes can only be explained in terms of normal B-cell development, if the second (functional) IGH allele is deleted, which was probably the case in most patients. Therefore, defects at the DNA level are responsible for the lack of IgH protein production in most $\mathrm{IgH}^{-}$MM patients. (Blood. 2000;96:1087-1093)

$\odot 2000$ by The American Society of Hematology

\section{Introduction}

Multiple myeloma (MM) is a clonal B-lineage malignancy affecting terminally differentiated bone marrow (BM) plasma cells bearing functional $\mathrm{V}_{\mathrm{H}}-\left(\mathrm{D}_{\mathrm{H}}\right)-\mathrm{J}_{\mathrm{H}}$ gene rearrangements with somatic hypermutations. ${ }^{1,2}$ The lack of intraclonal diversity in the hypermutation pattern indicates that malignant transformation occurred after positive selection in germinal centers. ${ }^{1,2}$ It has been suggested that identical clonotypic cells but having the morphology and immunophenotype of mature B cells, can be detected in peripheral blood (PB) of patients with MM. ${ }^{3,4}$ Based on extensive studies, the pathogenesis of $\mathrm{MM}$ is believed to be a multistep transformation process (reviewed in Hallek et $\mathrm{al}^{5}$ ). One of the presumably earliest oncogenic events is a translocation involving the immunoglobulin heavy chain $(I G H)$ gene locus (chromosome 14q32.3), which is the result of illegitimate $I G H$ class switch processes. ${ }^{5,6}$ Chromosome translocations involving $I G H$ genes occur in most $\mathrm{MM}$ and several recurrent partner loci have been identified. ${ }^{6-15}$

Classical MM is characterized by the presence of osteolytic bone lesions and overproduction of structurally homogenous immunoglobulins (Ig), which can be detected as a monoclonal peak (M-protein) on serum or urine electrophoresis. Depending on the tumor mass in the BM, additional characteristic clinical features can be observed including anemia, hypercalcemia, and renal insufficiency. ${ }^{16}$ Besides the classical presentation of MM, several forms with atypical or absent M-protein are distinguishable. In up to $20 \%$ of MM cases only Ig light chain protein is detected in serum or urine without detectable $\operatorname{Ig}$ heavy chains $(\operatorname{IgH})$ : the so-called

From the Department of Immunology and Department of Hematology, Erasmus University Rotterdam/University Hospital Rotterdam, Rotterdam, The Netherlands; Department of Paediatric Haematology and Chemotherapy, Silesian Medical Academy, Zabrze, Poland.

Submitted December 27, 1999; accepted March 30, 2000.

Reprints: J. J. M. van Dongen, Department of Immunology, Erasmus Univer- light chain (Bence-Jones) disease. In contrast, heavy chain disease is characterized by abnormally short monoclonal $\operatorname{IgH}$ proteins in serum without associated light chains. Nonsecretory MM without detectable M-protein in serum occurs in approximately $1 \%$ to $5 \%$ of MM patients. ${ }^{17-21}$ In about $85 \%$ of these cases intracellular Ig molecules are clearly detectable, suggesting an underlying defect in Ig excretion (nonexcretory MM), whereas the remaining $15 \%$ of cases have no detectable intracellular IgH and Ig light chains (true nonproducer $\mathrm{MM}$ ), implying that the latter cases represent a rare subgroup ( $<1 \%$ of all MM cases). ${ }^{18,21}$

The molecular background of the complete absence of $\mathrm{IgH}$ protein production in light chain disease and in true nonproducer MM (grouped together as $\mathrm{IgH}^{-} \mathrm{MM}$ ) is not fully clarified. We aimed therefore at identifying the molecular features responsible for the absence of $\mathrm{IgH}$ protein synthesis in $\mathrm{IgH}^{-} \mathrm{MM}$.

\section{Patients, materials, and methods}

\section{Patients}

Bone marrow $(\mathrm{n}=9), \mathrm{PB}(\mathrm{n}=1)$, or tissue biopsies $(\mathrm{n}=2 ; 1$ skin biopsy and 1 tonsil) were obtained from $12 \mathrm{MM}$ patients, aged 35 to 78 years, without production of $\operatorname{IgH}$ protein chains at initial diagnosis or during the course of their disease. Morphologic examination of the cell samples revealed that the percentages of plasma cells ranged from $20 \%$ to $90 \%$. In 9 patients the plasma cells produced Ig light chain proteins, whereas in the

sity Rotterdam, PO Box 1738, 3000 DR Rotterdam, The Netherlands.

The publication costs of this article were defrayed in part by page charge payment. Therefore, and solely to indicate this fact, this article is hereby marked "advertisement" in accordance with 18 U.S.C. section 1734.

(C) 2000 by The American Society of Hematology 
other 3 patients no evidence for Ig light chain production was found. The latter 3 patients (MM-10, MM-11, and MM-12) were diagnosed as true nonproducer MM. Immunoelectrophoresis demonstrated that in all 9 patients with monoclonal $\mathrm{CyIg \kappa}^{+}$or $\mathrm{CyIg} \lambda^{+}$plasma cells monoclonal Ig light chains were present in serum or urine or both at the time of investigation. Two patients (MM-4 and MM-8) showed high frequencies of plasma cells in their PB. In the other 10 patients no plasma cells were found in $\mathrm{PB}$ on cytomorphologic examination.

\section{Immunophenotyping of mononuclear cells (MNC) and plasma cells in tissue biopsies}

Mononuclear cells were isolated from BM or PB samples by Ficoll (density $1.077 \mathrm{~g} / \mathrm{mL}$; Pharmacia, Uppsala, Sweden) density centrifugation. In patients MM-10 and MM-11, snap frozen skin and tonsil biopsies, respectively, were used for immunohistology and molecular studies.

The MNC of the $10 \mathrm{BM}$ or PB samples as well as the tissue biopsies from patients MM-10 and MM-11 were analyzed for surface expression of CD10 (VIL-A1), CD19 (Leu-12), CD38 (Leu-17) antigen, and HLA-DR (L243) as well as for cytoplasmic expression of IgM, IgD, IgG, IgA, IgE, Igא, and Ig $\lambda$. The Leu monoclonal antibodies and anti-HLA-DR antibody were obtained from Becton Dickinson (San Jose, CA) and VIL-A1 was a gift from Dr W. Knapp (Vienna, Austria). The antihuman Ig antibodies were polyspecific and obtained from Nordic Immunological Laboratories (Tilburg, The Netherlands). The monoclonal antibodies were used in indirect immunofluorescence assays with a fluorescein isothiocyanate (FITC)conjugated goat antimouse Ig serum (Central Laboratory Blood Transfusion Service, Amsterdam, The Netherlands) as second-step reagent. The antihuman Ig antibodies were directly conjugated with either FITC or tetrahodamine isothiocyanate (TRITC) and used for $\operatorname{IgH} / \operatorname{Ig\kappa }$ or $\mathrm{IgH} / \mathrm{Ig} \lambda$ double stainings to confirm the absence of cytoplasmic IgM, IgD, IgG, IgA, and $\operatorname{IgE}$ protein chains in the Ig light chain-positive MM cells. Fluorescence stainings were evaluated using fluorescence microscopes (Zeiss, Oberkochen, Germany). ${ }^{22}$

\section{Southern blot analysis}

DNA was isolated from frozen MNC $(\mathrm{n}=10)$ or from tissue samples $(\mathrm{n}=$ 2), digested, and blotted to nylon membranes as described previously. ${ }^{23}$

IGH gene rearrangements were studied by use of ${ }^{32} \mathrm{P}$ labeled IGHJ6, $\mathrm{C} \mu$, $\mathrm{C} \gamma, \mathrm{C} \alpha$, and $\mathrm{C} \epsilon$ probes. ${ }^{24-28}$ The IGHJ6 probe (DAKO Corporation, Carpinteria, CA) was used in BgIII and BamHI/HindIII digests and in EcoRI, HindIII, or BamHI digests for confirmation. The $\mathrm{C} \mu$ probe was used in BamHI digests, whereas the other $\mathrm{C}_{\mathrm{H}}$ probes were used in EcoRI, HindIII, or BamHI digests. ${ }^{23}$

The $I G K$ gene rearrangements were studied with the ${ }^{32} \mathrm{P}$-labeled IGKJ5, IGKC, and IGKDE probes (DAKO). ${ }^{29}$ The IGKJ5 probe was used in EcoRI, HindIII, BglII, and BamHI digests, whereas the IGKC and IGKDE probes were used in $B g l \mathrm{II}$ and BamHI digests. ${ }^{29}$

The $I G L$ gene rearrangements were studied with the ${ }^{32} \mathrm{P}$-labeled IGLC3 probe (DAKO), which detects $95 \%$ of all $\mathrm{J}_{\lambda}-\mathrm{C}_{\lambda}$ gene rearrangements in EcoRI/HindIII digests. ${ }^{30}$

\section{Polymerase chain reaction (PCR) amplification and heteroduplex analysis of PCR products}

The PCR analysis was essentially performed as described previously. ${ }^{31,32}$ In each $50 \mu \mathrm{L}$ PCR reaction $50 \mathrm{ng}$ DNA sample, $6.3 \mathrm{pmol}$ of the $5^{\prime}$ and $3^{\prime}$ oligonucleotide primers, and $0.5 \mathrm{U}$ AmpliTaq Gold polymerase (PE Biosystems, Foster City, CA) were used. The sequences of the oligonucleotides used for amplification of complete $\mathrm{V}_{\mathrm{H}}-\mathrm{J}_{\mathrm{H}}$ and incomplete $\mathrm{D}_{\mathrm{H}}-\mathrm{J}_{\mathrm{H}}$ gene rearrangements as well as for $\mathrm{V}_{\mathrm{K}}-\mathrm{J}_{\mathrm{K}}$ rearrangements were published previously. ${ }^{33-36}$ PCR conditions were: preactivation of the enzyme for 10 minutes at $94^{\circ} \mathrm{C}$, followed by 35 cycles of 45 seconds at $92^{\circ} \mathrm{C}, 90$ seconds at $60^{\circ} \mathrm{C}$, and 2 minutes at $72^{\circ} \mathrm{C}$ using a Perkin-Elmer 480 thermal cycler $(\mathrm{PE}$ Biosystems). After the last cycle an additional extension step of 10 minutes at $72^{\circ} \mathrm{C}$ was performed. Appropriate positive and negative controls were included in all experiments. ${ }^{32}$

To distinguish between polyclonal and monoclonal rearrangements we performed heteroduplex analysis of the obtained PCR products. In short, the PCR products were denatured at $94^{\circ} \mathrm{C}$ for 5 minutes to obtain singlestranded PCR products. Subsequently the single-stranded products were cooled to $4^{\circ} \mathrm{C}$ for 60 minutes to induce random renaturation (duplex formation) ${ }^{37}$ In case of monoclonal gene rearrangements homoduplexes are formed (identical junctional regions), whereas heteroduplexes are found in case of polyclonal gene rearrangements (heterogeneous junctional regions). The obtained duplexes were immediately loaded on $6 \%$ nondenaturing polyacrylamide gels in $0.5 \times$ Tris-borate-EDTA (TBE) buffer, run at room temperature, and visualized by ethidium bromide staining to discriminate between the presence of rapidly migrating homoduplex bands or slowly migrating heteroduplexes smears. ${ }^{37}$ A 100-bp DNA ladder (Promega Corporation, Madison, WI) was used as size marker

\section{Sequence analysis of IGH and IGK gene rearrangements}

Clonal PCR products as found by heteroduplex analysis were directly sequenced. Sequencing was performed using the dye-terminator cycle sequencing kit with AmpliTaq DNA polymerase FS on an ABI 377 sequencer (PE Biosystems) as described before. ${ }^{34} \mathrm{~V}_{\mathrm{H}}, \mathrm{V}_{\mathrm{K}}, \mathrm{D}_{\mathrm{H}}, \mathrm{J}_{\mathrm{H}}$ and $\mathrm{J}_{\mathrm{K}}$ segments were identified using DNAPLOT software (W. Müller, H-H. Althaus, University of Cologne, Germany) by searching for homology with all known human germline $\mathrm{V}_{\mathrm{H}}, \mathrm{V}_{\mathrm{K}}, \mathrm{D}_{\mathrm{H}}, \mathrm{J}_{\mathrm{H}}$, and $\mathrm{J}_{\mathrm{K}}$ sequences obtained from the VBASE directory of human Ig genes (http://www.mrc-cpe.cam.ac.uk/ imt-doc/). ${ }^{38}$

\section{Northern blot analysis}

Total RNA was isolated with the $\mathrm{LiCl} /$ urea method $^{39}$ from frozen $\mathrm{MNC}$ of BM samples from 6 patients with light chain MM of whom sufficient cells were available. Fifteen micrograms of total RNA was size-fractionated in $1.0 \%$ agarose gel containing formaldehyde and transferred to a Biodyne nylon membrane (Pall Ultrafine Filtration Corp, Glen Cove, NY). The above-mentioned $\mathrm{C} \kappa, \mathrm{C} \mu, \mathrm{C} \gamma, \mathrm{C} \alpha$, and $\mathrm{C} \epsilon$ DNA probes were used for detection of $I G K$ and $I G H$ transcripts. Total RNA from the human B-cell lines ROS-17, EB4B, ROS-15, and U266 were used as positive controls for the detection of $\operatorname{IgM}, \operatorname{IgG}, \operatorname{Ig} A$, and $\operatorname{IgE}$ transcripts, respectively.

\section{Results}

\section{Immunophenotyping}

Immunophenotyping of the MNC from the 9 light chain MM patients and the nonproducer patient MM-12 as well as immunohistology of the skin and tonsil biopsies from the other 2 nonproducer patients (MM-10 and MM-11) demonstrated that the malignant plasma cells in all 12 patients did not contain IgH chains, whereas $\operatorname{Ig\kappa }$ chain and $\operatorname{Ig} \lambda$ chains were found in the plasma cells from 8 patients (MM-1 to MM-8) and 1 patient (MM-9), respectively (Table 1). In 3 patients (MM-10, MM-11, and MM-12) neither Igк nor $\operatorname{Ig} \lambda$ chains were detected (Table 1). The plasma cells in all 12 patients were negative in CD10, CD19, and HLA-DR staining, but positive in CD38 staining.

\section{Configuration of $I G H$ genes}

In 10 patients clonal rearrangements of $\mathrm{J}_{\mathrm{H}}$ gene segments were found on only 1 allele (MM-1 to MM-7, MM-9, MM-10, and MM-12), in 1 patient on both alleles (patient MM-11), and in 1 case (patient MM-8) the $\mathrm{J}_{\mathrm{H}}$ and $\mathrm{C}_{\mu}$ regions were deleted on both alleles (Table 1, Figure 1). In some patients the presence of normal non-B cells with germline $I G H$ genes might hamper the detection of a monoallelic $I G H$ gene deletion. However, based on the percentages of malignant plasma cells and the relative density of rearranged and germline bands, the absence or presence of a deleted second allele could be estimated in most cases. In fact, we concluded that in at 
Table 1. IGH gene configuration in MM patients based on Southern blotting, heteroduplex PCR analysis, and sequencing

\begin{tabular}{|c|c|c|c|c|c|c|c|c|c|c|c|c|}
\hline Patients & MM-1 & MM-2 & MM-3 & MM-4 & MM-5 & MM-6 & MM-7 & MM-8 & MM-9 & MM-10 & MM-11 & MM-12 \\
\hline MM phenotype & $\lg \kappa^{+}$ & $\lg \kappa^{+}$ & $\lg \kappa^{+}$ & $\lg \kappa^{+}$ & $\lg \kappa^{+}$ & $\lg \kappa^{+}$ & $\lg \kappa^{+}$ & $\lg \kappa^{+}$ & $\lg \lambda^{+}$ & $\begin{array}{l}\text { True non- } \\
\text { producer }\end{array}$ & $\begin{array}{l}\text { True non- } \\
\text { producer }\end{array}$ & $\begin{array}{l}\text { True non- } \\
\text { producer }\end{array}$ \\
\hline $\begin{array}{l}\text { Tumor load } \\
\quad \text { (cell sample) }\end{array}$ & $35 \%(B M)$ & $25 \%(B M)$ & $20 \%(B M)$ & $90 \%(\mathrm{BM})$ & $80 \%(\mathrm{BM})$ & $80 \%(\mathrm{BM})$ & $30 \%(\mathrm{BM})$ & $80 \%(\mathrm{~PB})$ & $60 \%(\mathrm{BM})$ & $25 \%$ (skin) & $70 \%$ (tonsil) & $35 \%(B M)$ \\
\hline \multicolumn{13}{|l|}{ Southern blotting* } \\
\hline JH region & $\mathrm{R} / \mathrm{G}$ & $\mathrm{R} / \mathrm{G}$ & $\mathrm{R} / \mathrm{D}$ & $\mathrm{R} / \mathrm{D}$ & $\mathrm{R} / \mathrm{D}$ & $\mathrm{R} / \mathrm{G}$ & $\mathrm{R} / \mathrm{G}$ or $\mathrm{D}$ & $\mathrm{D} / \mathrm{D}$ & $\mathrm{R} / \mathrm{G}$ & $\mathrm{R} / \mathrm{G}$ or $\mathrm{D}$ & $\mathrm{R} / \mathrm{R}$ & $\mathrm{R} / \mathrm{D}$ \\
\hline $\mathrm{C} \mu$ & $\mathrm{R}^{\mathrm{NC}} / \mathrm{G}$ & $D / G$ & $\mathrm{R}^{\mathrm{C} / \mathrm{G}}$ & $\mathrm{R}^{\mathrm{C}} / \mathrm{D}$ & $D / G$ & $\mathrm{R}^{\mathrm{C} / \mathrm{G}}$ & $\mathrm{R}^{\mathrm{C}} / \mathrm{G}$ & $D / G$ & $\mathrm{R}^{\mathrm{NC} / \mathrm{G}}$ & $\mathrm{R} / \mathrm{G}$ & $\mathrm{D} / \mathrm{D}$ & $D / G$ \\
\hline $\mathrm{C}_{\gamma} \dagger$ & $G$ & $D / G$ & $\mathrm{G}$ & $\mathrm{G}$ & $D / G$ & $\mathrm{G}$ & $G$ & $G$ & $G$ & $\mathrm{G}$ & $G$ & $G$ \\
\hline $\mathrm{C} \alpha$ & $G$ & $\mathrm{R}^{\mathrm{C}} / \mathrm{G}$ & $G$ & $G$ & $\mathrm{R}^{N C} / \mathrm{G}$ & $G$ & $G$ & $\mathrm{R} / \mathrm{G}$ & $\mathrm{G}$ & $G$ & $\mathrm{R}^{\mathrm{NC} / \mathrm{G}}$ & $\mathrm{R}^{\mathrm{C}} / \mathrm{G}$ \\
\hline $\mathrm{C} \epsilon$ & $G$ & $G$ & $\mathrm{R}^{N C} / \mathrm{G}$ & $\mathrm{G}$ & $D / G$ & $G$ & $\mathrm{G}$ & $\mathrm{G}$ & $G$ & $G$ & $D / G$ & $\mathrm{G}$ \\
\hline \multicolumn{13}{|l|}{$\begin{array}{l}\text { Heteroduplex PCR } \\
\text { and sequencing }\end{array}$} \\
\hline Gene segments & $V_{H} 1-24 / J_{H} 3$ & negative & ND & $D_{H} 3-16 / J_{H} 4$ & $D_{H} 2-2 / J_{H} 4$ & $\mathrm{D}_{\mathrm{H}} 2-2 / \mathrm{J}_{\mathrm{H}} 5$ & $\mathrm{D}_{\mathrm{H}} 4-23 / \mathrm{J}_{H} 6$ & NA & $V_{H} 3-11 / J_{H} 5$ & $D_{H} 1-26 / J_{H} 5$ & $V_{H} 2-5 / J_{H} 4$ & $V_{H} 1-18 / J_{H} 4$ \\
\hline Reading frame & + & NA & ND & NA & NA & NA & NA & NA & + & NA & - & + \\
\hline $\begin{array}{l}\text { Somatic hyper- } \\
\text { mutation }\end{array}$ & + & NA & ND & - & - & - & - & NA & + & - & - & + \\
\hline
\end{tabular}

${ }^{*}$ Gene configuration: $\mathrm{G}$ indicates germline allele or no rearrangements detectable; $\mathrm{R}$, rearranged allele, $\mathrm{R}^{\mathrm{C}}$, rearranged $\mathrm{C}_{H}$ band, which comigrates with the rearranged $\mathrm{J}_{H}$ band; $R^{N C}$, rearranged $C_{H}$ band, which does not comigrate with the rearranged $J_{H}$ band; $D$, deleted allele.

†lt was not possible to determine the configuration of the $\mathrm{C} \gamma$ gene regions, due to the complexity of the banding patterns (see text).

ND indicates not determined; NA, not applicable.

least 4 of the 10 patients with monoallelic $\mathrm{J}_{\mathrm{H}}$ rearrangements the second allele was deleted, that in 2 additional patients the second allele might be deleted, whereas in the other 4 patients the second $I G H$ allele seemed to be in germline configuration (Figure 1).

Detailed heteroduplex PCR analysis of the $I G H$ locus was performed in 11 patients using 19 primer combinations (6 IGH framework- $1 \mathrm{~V}_{\mathrm{H}}$-family specific primers, $6 \mathrm{~V}_{\mathrm{H}}$-leader primers, and 7 family-specific $D_{H}$ primers in combination with $1 J_{H}$ consensus primer). In a total of 9 patients 9 monoclonal homoduplexes were found out of the total $12 \mathrm{~J}_{\mathrm{H}}$ gene rearrangements as identified by Southern blotting; in 1 patient (MM-3) insufficient DNA was available for detailed PCR studies, and PCR analyses in 2 other patients (MM-2 and MM-11) failed to detect a $\mathrm{J}_{\mathrm{H}}$ rearrangement (Table 1; Figure 2). Only 4 of the detected $\mathrm{J}_{\mathrm{H}}$ rearrangements were complete $\mathrm{V}_{\mathrm{H}^{-}}\left(\mathrm{D}_{\mathrm{H}}\right)-\mathrm{J}_{\mathrm{H}}$ rearrangements and sequence analysis revealed 4 different functional $\mathrm{V}_{\mathrm{H}}$ gene segments $\left(\mathrm{V}_{\mathrm{H}} 1-18, \mathrm{~V}_{\mathrm{H}} 1-24\right.$, $\mathrm{V}_{\mathrm{H}} 2-5$, and $\mathrm{V}_{\mathrm{H}} 3-11$ ). Three of these rearrangements were in a proper reading frame with evidence of somatic hypermutation (patients MM-1, MM-9, and MM-12), whereas the fourth rearrangement was out-of-frame and unmutated (patient MM-11). Five rearrangements concerned incomplete $D_{H}-J_{H}$ joinings, using 4 different $\mathrm{D}_{\mathrm{H}}$ gene segments $\left(\mathrm{D}_{\mathrm{H}} 1-26, \mathrm{D}_{\mathrm{H}} 2-2, \mathrm{D}_{\mathrm{H}} 3-16\right.$, and $\left.\mathrm{D}_{\mathrm{H}} 4-23\right)$.
In 2 of these 5 cases the second $I G H$ allele was deleted, in 2 other cases the second allele might be deleted, whereas in 1 case the second allele seemed to be germline. Based on the knowledge of the gene segments identified in the clonal PCR products together with the complete sequence of the human $I G H$ locus, ${ }^{40,41}$ the theoretical sizes of restriction fragments containing the respective rearrangements were calculated and indeed found to be concordant with the sizes of the respective rearranged bands in Southern blot analysis.

The configuration of the $I G H$ genes was further investigated by use of $\mathrm{C} \mu, \mathrm{C} \gamma, \mathrm{C} \alpha$, and $\mathrm{C} \epsilon$ probes (Table 1). In 7 patients a rearranged $C_{\mu}$ gene band was found, which comigrated with the $\mathrm{J}_{\mathrm{H}}$ band in 5 of them (patients MM-3, MM-4, MM-6, MM-7, and MM-10), indicating that no $I G H$ class switch had occurred; at least 4 of these 5 rearrangements concerned a $D_{H}-J_{H}$ joining (patient MM-3 was not studied by PCR), which explains the absence of $I G H$ class switch. In the other 2 cases (patients MM-1 and MM-9) the rearranged $\mathrm{J}_{\mathrm{H}}$ and $\mathrm{C}_{\mu}$ regions were not present on the same restriction fragments, suggesting that illegitimate recombination with a breakpoint in the $\mathrm{J}_{\mathrm{H}^{-}}-\mathrm{C}_{\mu}$ area had occurred thereby making the in-frame $\mathrm{V}_{\mathrm{H}^{-}} \mathrm{J}_{\mathrm{H}}$ joining in these 2 patients nonfunctional. The Southern blot analyses with the $\mathrm{C} \gamma$ probe did not provide reliable
Figure 1. IGH and IGK gene configuration of $6 \mathrm{IgH}^{-} /$ Ig $\kappa^{+}$MM patients. (A) IGHJ6 probe hybridization to Bg/l digests or BamHI/HindllI digests. (B) IGKJ5 probe hybridization to EcoRI digests.
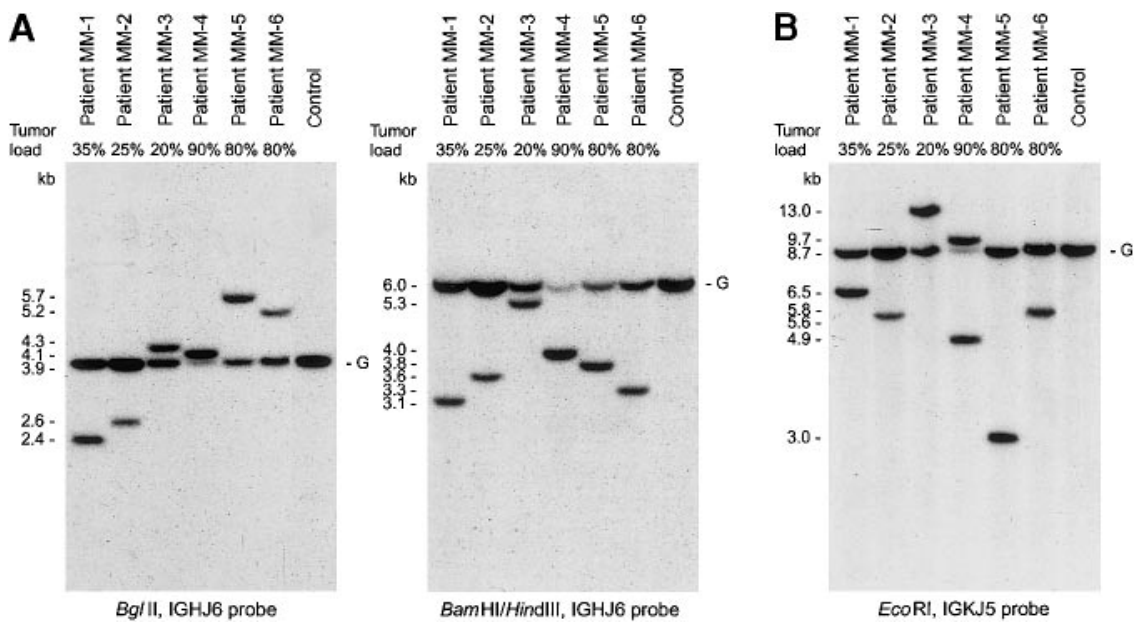


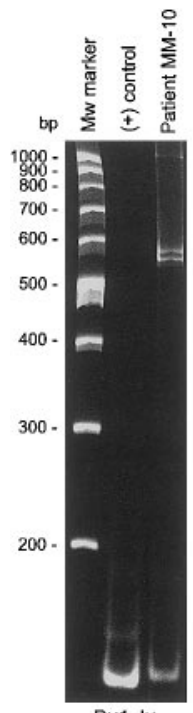

DH1-JH

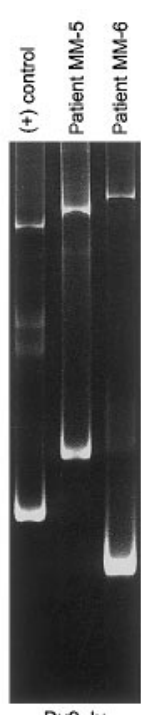

DH2-JH

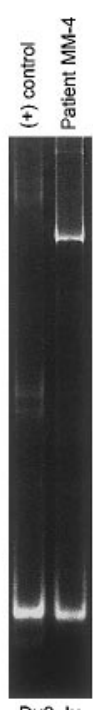

DH3-JH

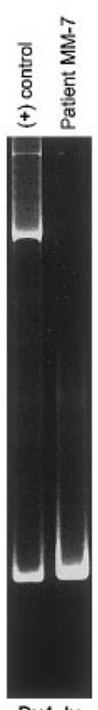

DH4-JH

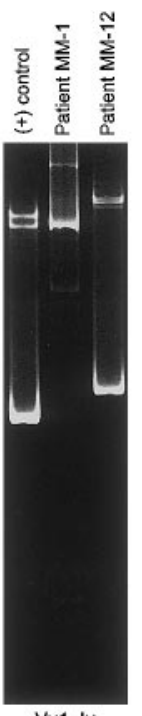

VH1-JH
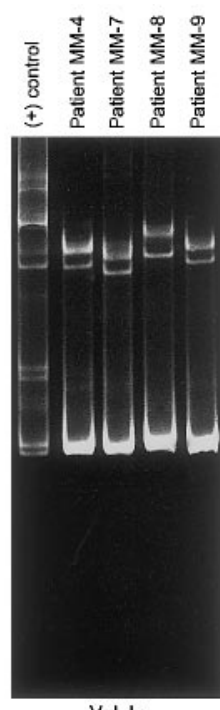

$\mathrm{V} \times \mathrm{K}-\mathrm{J} \mathrm{K}$

Figure 2. Heteroduplex PCR analysis in several $\mathrm{IgH}^{-}$ MM patients to distinguish between polyclonal and monoclonal IGH and IGK gene rearrangements. Clonal homoduplexes found with particular primer combinations are illustrated as compared to positive controls. In patient MM-1, the size of the homoduplex found with the $V_{H} 1-J_{H}$ PCR was essentially larger than predicted. Sequence analysis showed a PCR product with a $V_{H} 1-24 / J_{H} 3$ rearrangement extended to the $\mathrm{J}_{\mathrm{H}} 5$ segment with extensive somatic hypermutation of the $J_{H} 3$ gene (resulting in loss of the primer annealing site) and deletion of the $\mathrm{J}_{4} 4$ segment most probably owing to an abnormal somatic mutation process. ${ }^{48}$

information concerning rearrangements and $I G H$ class switch, due to the complex banding pattern, which is caused by the $5 \mathrm{C}_{\gamma}$ gene segments and their genetic polymorphisms. ${ }^{23}$ Nevertheless, in patient MM-2 the $\mathrm{C} \gamma$ probe allowed the detection of $\mathrm{C}_{\gamma}$ gene deletions, which could be explained by a presumably normal $I G H$ class switch to $\mathrm{C}_{\alpha}$, whereas in patient MM-5 extensive illegitimate $\mathrm{C}_{\gamma}$ gene deletions were found on 1 allele. Analyses with the $\mathrm{C} \alpha$ probe revealed a monoallelic rearrangement in 5 of the 12 patients. In patients MM-2 and MM-12, the rearranged bands comigrated with a rearranged $\mathrm{J}_{\mathrm{H}}$ gene band, suggesting that an IgA class switch had occurred. In the other 3 patients (patients MM-5, MM-8, and MM-11) no proof for close linkage between the $J_{H}$ region and the rearranged $\mathrm{C}_{\alpha}$ region was found, which might be due to illegitimate IGH class switches. Finally, in 1 case (patient MM-3) a rearranged band was found with the C€ probe. This patient contained a $\mathrm{J}_{\mathrm{H}}-\mathrm{C}_{\mu}$ rearrangement on 1 allele with deletion of the $\mathrm{J}_{\mathrm{H}}$ region on the other allele. The latter suggests that the detected $\mathrm{C}_{\epsilon}$ rearrangement might be caused by deletion of a large part of the $I G H$ locus.

\section{Configuration of IGK and IGL genes}

In 6 of the $8 \mathrm{Ig \kappa}^{+} \mathrm{MM}$ patients a monoallelic rearrangement in the $\mathrm{J}_{\mathrm{K}}-\mathrm{C}_{\mathrm{K}}$ area was found (Figure 1), while the $\mathrm{J}_{\mathrm{K}}-\mathrm{C}_{\mathrm{K}}$ region on the second allele was in germline configuration in 5 patients and deleted in the sixth patient (MM-2), owing to a $\mathrm{V}_{\kappa}$ to kappa deleting element (Kde) rearrangement (Table 2). In the remaining 2 $\mathrm{Ig \kappa}^{+}$patients (MM-3 and MM-4), $\mathrm{V}_{\mathrm{K}}-\mathrm{J}_{\mathrm{\kappa}}$ rearrangements were found on 1 allele; the other allele contained a $V_{K}-J_{K}$ rearrangement in combination with a $\mathrm{C}_{\mathrm{K}}$ deletion. Both $I G L$ alleles were in germline configuration in all $8 \mathrm{Ig \kappa}^{+}$patients. The patient with $\operatorname{Ig} \lambda$ light chain MM had biallelic IGL gene rearrangements in combination with biallelic nonfunctional $I G K$ gene rearrangements owing to intron RSS-Kde and Vк-Kde recombinations.

Two nonproducer MM patients (MM-10 and MM-11) had a monoallelic $\mathrm{V}_{\mathrm{K}}-\mathrm{J}_{\mathrm{K}}$ gene rearrangement with the $I G L$ genes in germline configuration. Interestingly, the third nonproducer MM patient (MM-12) had biallelic $I G K$ rearrangements with deleted $\mathrm{C}_{\mathrm{K}}$

Table 2. Ig light chain gene configuration in MM patients based on Southern blotting, heteroduplex PCR analysis, and sequencing

\begin{tabular}{|c|c|c|c|c|c|c|c|c|c|c|c|c|}
\hline Patients & $\mathrm{MM}-1$ & MM-2 & MM-3 & $\mathrm{MM}-4$ & MM-5 & MM-6 & MM-7 & MM-8 & MM-9 & MM-10 & MM-11 & MM-12 \\
\hline MM phenotype & $\lg \kappa^{+}$ & $\lg \kappa^{+}$ & $\lg \kappa^{+}$ & $\lg ^{+}$ & $\lg ^{+}$ & $\lg \kappa^{+}$ & $\lg \kappa^{+}$ & $\lg \kappa^{+}$ & $\lg \lambda^{+}$ & $\begin{array}{l}\text { True non- } \\
\text { producer }\end{array}$ & $\begin{array}{l}\text { True non- } \\
\text { producer }\end{array}$ & $\begin{array}{l}\text { True non- } \\
\text { producer }\end{array}$ \\
\hline Tumor load & $35 \%$ & $25 \%$ & $20 \%$ & $90 \%$ & $80 \%$ & $80 \%$ & $30 \%$ & $80 \%$ & $60 \%$ & $25 \%$ & $70 \%$ & $35 \%$ \\
\hline \multicolumn{13}{|l|}{$\begin{array}{l}\text { IGK: Southern blot } \\
\text { analysis* }\end{array}$} \\
\hline First allele & $V_{\kappa}-J_{\kappa}$ & $V_{\kappa}-J_{\kappa}$ & $V_{\kappa}-J_{\kappa}$ & $V_{K}-J_{K}$ & $V_{\kappa}-J_{\kappa}$ & $V_{\kappa}-J_{\kappa}$ & $V_{\kappa}-J_{\kappa}$ & $V_{\kappa}-J_{\kappa}$ & $V_{\kappa}$-Kde & $V_{\kappa}-J_{\kappa}$ & $V_{\kappa}-J_{\kappa}$ & $\begin{array}{l}\mathrm{V}_{\kappa}-\mathrm{J}_{\kappa}+ \\
\quad \text { intron-Kde }\end{array}$ \\
\hline Second allele & $\mathrm{G}$ & $V_{\kappa}-$ Kde & $\begin{array}{l}V_{\kappa}-J_{\kappa}+ \\
\quad \text { intron-Kde }\end{array}$ & $\begin{array}{l}V_{\kappa}-J_{\kappa}+ \\
\quad \text { intron-Kde }\end{array}$ & $\mathrm{G}$ & $\mathrm{G}$ & G & $\mathrm{G}$ & $\begin{array}{l}\mathrm{V}_{\mathrm{K}-\mathrm{J}}+ \\
\quad \text { intron-Kde }\end{array}$ & $\mathrm{G}$ & $V_{\kappa}-K d e$ & $\begin{array}{l}\mathrm{V}_{\mathrm{K}-\mathrm{J}}+ \\
\quad \text { intron-Kde }\end{array}$ \\
\hline \multicolumn{13}{|l|}{ IGK: PCR } \\
\hline Gene segments & $\begin{array}{c}\mathrm{V}_{\kappa} 4-1 / \\
\mathrm{J}_{\kappa} 2\end{array}$ & $\begin{array}{c}\text { Vк3-20/ } \\
J_{\kappa} 4\end{array}$ & ND & $\begin{array}{l}V_{\kappa} 1-12 / J_{\kappa} 4 \\
V_{\kappa} 2 D-29 / J_{\kappa} 4\end{array}$ & $\begin{array}{c}V_{\kappa} 1-5 / \\
J_{\kappa} 2\end{array}$ & $\begin{array}{c}\mathrm{V}_{\kappa} 3-20 / \\
\mathrm{J}_{\kappa} 4\end{array}$ & $\begin{array}{c}V_{\kappa} 1-33 / \\
J_{\kappa 2}\end{array}$ & $\begin{array}{c}V_{\kappa} 1-5 / \\
J_{\kappa} 1\end{array}$ & $\begin{array}{l}\mathrm{V}_{\kappa} 1 \mathrm{D}-12 / \\
\mathrm{J}_{\kappa} 4\end{array}$ & Negative & $V_{\kappa} 1-39 / J_{\kappa} 2$ & $V_{\kappa} 1 \mathrm{D}-43 / \mathrm{J}_{\kappa} 5$ \\
\hline Reading frame & + & + & ND & $+1-$ & + & + & + & + & - & NA & + & - \\
\hline $\begin{array}{l}\text { Somatic hyper- } \\
\text { mutation }\end{array}$ & + & + & ND & $+1-$ & + & + & + & + & - & NA & + & - \\
\hline \multicolumn{13}{|l|}{$\begin{array}{l}\text { IGL: Southern blot } \\
\text { analysis }\end{array}$} \\
\hline $\mathrm{J} \lambda-\mathrm{C} \lambda$ regions & G & G & $\mathrm{G}$ & G & G & G & G & $G$ & $\mathrm{~V} \lambda-\mathrm{J} \lambda_{1} / \mathrm{V} \lambda-\mathrm{J} \lambda_{2}$ & $\mathrm{G}$ & $\mathrm{G}$ & $\mathrm{V} \lambda-\mathrm{J} \lambda_{1} / \mathrm{V} \lambda-\mathrm{J} \lambda_{2}$ \\
\hline
\end{tabular}

*The presence of a $V_{K}-J_{K}$ rearrangement was assumed from the finding of a rearranged band with the IGKJ5 probe. Rearranged bands found with the IGKDE probe were interpreted as $V_{\kappa}-K d e$ joining, if accompanied by deletion of $\mathrm{J}_{\kappa}$ and $\mathrm{C}_{\kappa}$ segments, and as intron-Kde rearrangements, if they were found on the same restriction fragment as $V_{\kappa}-J_{\kappa}$ rearrangements (IGKJ5 probe) together with a $\mathrm{C}_{\kappa}$ gene deletion (IGKC probe).

ND indicates not determined; NA, not applicable. 
segments on both alleles (intron RSS-Kde recombinations) and biallelic $I G L$ gene rearrangements.

Heteroduplex PCR analysis of $\mathrm{V}_{\mathrm{K}}-\mathrm{J}_{\mathrm{K}}$ gene rearrangements was performed in 11 patients with $4 \mathrm{~V}_{\mathrm{K}}$ family-specific primers and $2 \mathrm{~J}_{\mathrm{K}}$ reverse primers. Eleven monoclonal homoduplexes were found in 10 patients (Table 2 and Figure 2), including 8 in-frame rearrangements with moderate amounts of somatic mutations and 3 out-of-frame unmutated joinings. In the true nonproducer MM-10 no clonal $\mathrm{V}_{\mathrm{K}}-\mathrm{J}_{\mathrm{K}}$ PCR products could be identified, whereas in nonproducer MM-11 the identified $\mathrm{V}_{\mathrm{K}}-\mathrm{J}_{\mathrm{K}}$ gene rearrangement was in-frame.

\section{Transcription of $I g$ genes}

Six patients with $\mathrm{Ig \kappa}^{+}$light chain MM (patients MM-1, MM-2, MM-3, MM-4, MM-5, and MM-6) could be studied for the occurrence of Ig messenger RNA (mRNA) by use of Northern blot analysis. As expected, in all 6 patients high levels of $I G K$ mRNA were present. In patient MM-1 a trace IGM mRNA, high levels of $I G G$ mRNA and low levels of $I G A$ mRNA were found. In patient MM-2 no $I G H$ transcripts were detected. In patient MM-3 we found trace levels of $I G M$ and $I G G$ transcripts, which were essentially lower than the $I G K$ mRNA transcription levels, thereby suggesting that these low $I G H$ transcript levels were probably derived from the background of normal B cells. In patients MM-4 and MM-6 low or moderate levels of IGM transcripts were detected. Finally, in patient MM-5 a trace of $I G G$ mRNA and moderate levels of truncated IGA mRNA were found. IGE mRNA could not be detected in all 6 tested patients.

\section{Discussion}

Lack of $\operatorname{IgH}$ protein synthesis may be caused by abnormalities at several levels, for example, abnormalities at the DNA level (a defective gene with true nonsynthetic capability), aberrant transcription processes, aberrant translation processes, or rapid degradation of newly synthesized IgH protein. ${ }^{21}$ We mainly focused on detailed molecular analysis of the $I G H$ genes. Although seemingly normal $\mathrm{J}_{\mathrm{H}}$ gene rearrangements were found in all but 1 patient by Southern blotting, the further PCR-based identification of these rearrangements as well as Southern blot analysis of the downstream part of the $I G H$ locus with probes for the various constant gene segments revealed distinct molecular abnormalities explaining the absence of IgH proteins (summarized in Table 3).

Southern blot analysis in $10 \mathrm{MM}$ patients showed clonal $\mathrm{J}_{\mathrm{H}}$ rearrangements on only 1 allele. This is in striking contrast to normal B-cell development and most B-lineage malignancies, where $I G H$ gene rearrangements are generally found on both alleles. ${ }^{42-44}$ Therefore, one would have expected biallelic IGH gene rearrangements in most $\mathrm{MM}$ cases. In patient MM- 8 both $\mathrm{J}_{\mathrm{H}}$ alleles were deleted, which is an obvious reason for IgH negativity in this case. In 5 patients (MM-1, MM-3, MM-5, MM-9, and MM-11) the rearranged $\mathrm{J}_{\mathrm{H}}$ gene and $\mathrm{C}_{\mathrm{H}}$ gene segments were not linked, suggesting that illegitimate class switch recombination had separated the rearranged $\left(\mathrm{V}_{\mathrm{H}}\right)-\mathrm{D}_{\mathrm{H}}-\mathrm{J}_{\mathrm{H}}$ complex from a $\mathrm{C}_{\mathrm{H}}$ gene segment. This phenomenon can explain the IgH negativity in patients MM-1 and MM-9 with functional (in-frame) somatically mutated $\mathrm{V}_{\mathrm{H}^{-}}$ $\left(D_{H}\right)-J_{H}$ rearrangements. In patient MM-3 the illegitimate switch recombination resulted in the deletion of $1 \mathrm{~J}_{\mathrm{H}}$ allele, whereas the second $I G H$ allele, probably nonfunctional, did not undergo class switch. Unfortunately, we could not perform PCR/sequencing analysis due to insufficient DNA, but Northern blotting showed absence of the expected IGH mRNA levels in patient MM-3. In patients MM-5 and MM-11 additional reasons were found for $\operatorname{IgH}$ protein negativity, that is, an incomplete $\mathrm{D}_{\mathrm{H}}-\mathrm{J}_{\mathrm{H}}$ rearrangement and an out-of-frame $\mathrm{V}_{\mathrm{H}^{-}}\left(\mathrm{D}_{\mathrm{H}}\right)-\mathrm{J}_{\mathrm{H}}$ rearrangement, respectively (Table 3). The causative mechanism underlying the aberrant $\mathrm{C}_{\mathrm{H}}$ rearrangements in the above 5 patients is most probably a translocation involving the $I G H$ gene on chromosome 14q32.3, known to occur frequently in MM. Unfortunately, no cytogenetic data are available in our group of patients. Although chromosome aberrations with breakpoints in the $\mathrm{C}_{\mathrm{H}}$ region of the $I G H$ locus occur in the majority of MM patients, they seem to affect IgH protein production only in rare cases. ${ }^{6,8} \mathrm{In} \mathrm{IgH}^{+} \mathrm{MM}$ cases such translocations presumably occur on the nonproductive allele or involve switch regions downstream of a functional $\mathrm{V}_{\mathrm{H}}-\left(\mathrm{D}_{\mathrm{H}}\right)-\mathrm{J}_{\mathrm{H}}-\mathrm{C}$ complex. ${ }^{5}$ Even biallelic translocations involving $I G H$ genes may be accompanied by a normal $\mathrm{IgH}^{+}$phenotype. ${ }^{8,45}$ Nevertheless, our data clearly show that in at least 2 (but probably 3 ) of our patients an illegitimate class switch rearrangement seems to be the sole cause of the absence of $\mathrm{IgH}$ proteins, whereas in additional 2 cases, it appeared to be one of the causes for IgH negativity (Table 3 ).

In patient MM-2 extensive heteroduplex PCR analysis did not reveal any clonal $I G H$ gene rearrangement and also Northern blotting showed no $I G H$ gene transcription. This indicates that the $\mathrm{J}_{\mathrm{H}}$ gene rearrangement found by Southern blotting in this patient might also reflect an illegitimate recombination. In fact, translocations to $\mathrm{J}_{\mathrm{H}}$ gene segments (rather than to the switch regions) owing to abnormal $\mathrm{V}(\mathrm{D}) \mathrm{J}$ recombinase activity occur frequently in some subsets of non-Hodgkin lymphomas, but were previously also suggested to occur in MM and found in the MM-derived cell line FLAM-76. 6,11,46

Remarkably, in 5 patients heteroduplex PCR analysis showed that the single $I G H-\mathrm{J}_{\mathrm{H}}$ rearrangement detected by Southern blotting concerned an incomplete $\mathrm{D}_{\mathrm{H}}-\mathrm{J}_{\mathrm{H}}$ joining. In 2 of these patients (patients MM-4 and MM-5) the second allele (most probably having contained a functional $\mathrm{V}_{\mathrm{H}^{-}}\left(\mathrm{D}_{\mathrm{H}}\right)-\mathrm{J}_{\mathrm{H}}$ gene rearrangement) was

Table 3. Molecular abnormalities responsible for IgH negativity in the 12 MM patients

\begin{tabular}{|c|c|c|c|c|c|c|c|c|c|c|c|c|}
\hline Abnormality & MM-1 & MM-2 & MM-3 & MM-4 & MM-5 & MM-6 & MM-7 & MM-8 & MM-9 & $\mathrm{MM}-10$ & $\mathrm{MM}-11$ & $\mathrm{MM}-12$ \\
\hline Biallelic $\mathrm{J}_{H}$ deletion & - & - & - & - & - & - & - & + & - & - & - & - \\
\hline Illegitimate IGH class switch & + & - & $(+)$ & - & + & - & - & - & + & - & + & - \\
\hline No IGH mRNA & - & + & + & - & - & - & ND & ND & ND & ND & ND & ND \\
\hline Missing $\left(V_{H}\right)-D_{H^{-}} J_{H}$ PCR product ${ }^{*}$ & - & $+{ }^{*}$ & ND & - & - & - & - & - & - & - & $+^{*}$ & - \\
\hline Only $D_{H}-J_{H}$ with second allele deleted (or germline?) & - & - & ND & + & + & + & + & - & - & + & - & - \\
\hline Nonfunctional $V_{H}-D_{H}-J_{H}$ & - & - & ND & - & - & - & - & - & - & - & + & - \\
\hline Unexplained & - & - & - & - & - & - & - & - & - & - & - & + \\
\hline
\end{tabular}

Abbreviations: +, presence of abnormality; -, absence of abnormality; ND, not determined.

${ }^{*}$ The single $J_{H}$ rearrangement in patient MM-2 and 1 of the $2 J_{H}$ rearrangements in patient MM-11 could not be detected or identified by $V_{H}-J_{H}$ or $D_{H}-J_{H} P C R$ analysis, suggesting the presence of an aberrant $J_{H}$ rearrangement. 
deleted. However, in the remaining 3 patients Southern blot analysis suggested that the second allele might be in germline configuration, although we cannot exclude deletion of the second allele in 2 of the 3 cases because of the low tumor load (Table 1, Figure 1). Curiously, the $4 \mathrm{IgK}^{+}$positive $\mathrm{MM}$ patients with incomplete $\mathrm{D}_{\mathrm{H}}-\mathrm{J}_{\mathrm{H}}$ rearrangements had functional, somatically mutated $I G K$ gene rearrangements. We cannot explain this finding in terms of normal B-cell maturation because exclusive $\mathrm{D}_{\mathrm{H}}-\mathrm{J}_{\mathrm{H}}$ rearrangements, as found in our patients, are markers of the most immature B-cell precursors in BM and are in striking contrast with somatically mutated $V_{K}-J_{K}$ gene rearrangements, which are typical for mature $\mathrm{Ig}^{+}$(post-)germinal B cells. In fact, from an immunobiologic point of view, the precursor of each plasma cell and each MM should originally have expressed a functional Ig molecule to reach its final stage of B-cell maturation. Therefore, the most likely explanation for the absence of a functional IGH gene rearrangement in the 5 patients with exclusive $D_{H}-J_{H}$ rearrangements has to be that the second (functional) allele was deleted during or after the oncogenic process. This was indeed found in patients MM-4 and MM-5, might be true in patients MM-7 and MM-10, but seems not to be the case in patient MM-6 (Table 1). The high frequency of monoallelic $I G H$ gene rearrangements ( 10 of 12 cases) already suggested that in $\mathrm{IgH}^{-} \mathrm{MM}$ deletion of $1 \mathrm{IGH}$ allele is a frequent phenomenon.

Finally, we could not establish the reason for IgH negativity in 1 case (patient MM-12). Although on 1 allele $J_{H}$ and $C_{\mu}$ gene segments were deleted, the second allele contained a functional, in-frame, somatically mutated $\mathrm{V}_{\mathrm{H}} 1-18 / \mathrm{J}_{\mathrm{H}} 4$ rearrangement linked to a $\mathrm{C}_{\alpha}$ gene. Unfortunately, Northern blot analysis could not be performed due to insufficient cell material.

One of the few studies addressing the potential mechanisms for inability of $\operatorname{IgH}$ protein production in Bence-Jones MM, demonstrated lack of $I G H$ transcription in $6 \mathrm{IgH}^{-}$MM cases and 3 $\mathrm{IgH}^{-} \mathrm{MM}$ cell lines. ${ }^{47}$ The authors suggested alterations of the transcriptional apparatus as a major cause of failure to produce $\mathrm{IgH}$. However their analysis of the $I G H$ gene configuration was too limited to exclude defects at the DNA level. Kuipers et $\mathrm{a}^{46}$ used several fluorescence in situ hybridization techniques for studying $19 \mathrm{MM}$ cell lines, including 11 without $\mathrm{IgH}$ protein production. They concluded that the majority of $\mathrm{IgH}^{-}$cell lines contained abnormal $I G H$ genes owing to illegitimate $I G H$ class switch processes, presumably resulting from chromosome translocations involving 14q32.3. Curiously, 6 of $11 \mathrm{IgH}^{-}$cell lines were derived from Ig-producing MM patients. Therefore, secondary genetic changes during culturing might have caused $\mathrm{IgH}$ negativity in these cell lines.

The combined Southern blot and PCR data presented here show that in the vast majority of $\operatorname{IgH}^{-}$MM patients defects at the DNA level are responsible for the lack of $\operatorname{IgH}$ protein production. We conclude that in at least 9 of the 12 patients (Table 3) these defects concern illegitimate $I G H$ class switch rearrangements or illegitimate deletion of the functional $\mathrm{V}_{\mathrm{H}^{-}}$ $\left(D_{\mathrm{H}}\right)-\mathrm{J}_{\mathrm{H}}$ allele, which probably occurred during or after the malignant transformation process.

\section{Acknowledgments}

We are grateful to Prof dr R. Benner and Prof dr D. SońtaJakimczyk for their continuous support, Mr T. M. van Os for preparation of the figures and Mrs A. D. Korpershoek for her secretarial support.

\section{References}

1. Baker BW, Deane M, Gilleece MH, Johnston D, Scarffe JH, Norton JD. Distinctive features of immunoglobulin heavy chain variable region gene rearrangement in multiple myeloma. Leuk Lymphoma. 1994;14:291-301.

2. Vescio RA, Cao J, Hong $\mathrm{CH}$, et al. Myeloma lg heavy chain $\mathrm{V}$ region sequences reveal prior antigenic selection and marked somatic mutation but no intraclonal diversity. J Immunol. 1995;155: 2487-2497.

3. Szczepek AJ, Seeberger K, Wizniak J, Mant MJ, Belch AR, Pilarski LM. A high frequency of circulating $B$ cells share clonotypic Ig heavy-chain VDJ rearrangements with autologous bone marrow plasma cells in multiple myeloma, as measured by single-cell and in situ reverse transcriptase-polymerase chain reaction. Blood. 1998;92: 2844-2855.

4. Mitterer M, Oduncu F, Lanthaler AJ, et al. The relationship between monoclonal myeloma precursor B cells in the peripheral blood stem cell harvests and the clinical response of multiple myeloma patients. Br J Haematol. 1999;106:737743.

5. Hallek M, Bergsagel PL, Anderson KC. Multiple myeloma: increasing evidence for a multistep transformation process. Blood. 1998;91:3-21.

6. Bergsagel PL, Chesi M, Nardini E, Brents LA, Kirby SL, KuehI WM. Promiscuous translocations into immunoglobulin heavy chain switch regions in multiple myeloma. Proc Natl Acad Sci U S A. 1996;93:13931-13936.

7. Lai JL, Zandecki M, Mary JY, et al. Improved cytogenetics in multiple myeloma: a study of $151 \mathrm{pa}$ tients including 117 patients at diagnosis. Blood. 1995;85:2490-2497.

8. Nishida K, Tamura A, Nakazawa N, et al. The Ig heavy chain gene is frequently involved in chromosomal translocations in multiple myeloma and plasma cell leukemia as detected by in situ hybridization. Blood. 1997;90:526-534.

9. Richelda R, Ronchetti D, Baldini L, et al. A novel chromosomal translocation $\mathrm{t}(4 ; 14)(\mathrm{p} 16.3 ; \mathrm{q} 32)$ in multiple myeloma involves the fibroblast growthfactor receptor 3 gene. Blood. 1997;90:40624070 .

10. Sawyer JR, Lukacs JL, Munshi N, et al. Identification of new nonrandom translocations in multiple myeloma with multicolor spectral karyotyping. Blood. 1998;92:4269-4278.

11. Fonseca R, Witzig TE, Gertz MA, et al. Multiple myeloma and the translocation $t(11 ; 14)(q 13 ; q 32)$ : a report on 13 cases. Br J Haematol. 1998;101: 296-301.

12. Chesi M, Bergsagel PL, Shonukan OO, et al. Frequent dysregulation of the c-maf proto-oncogene at $16 q 23$ by translocation to an Ig locus in multiple myeloma. Blood. 1998;91:4457-4463.

13. Rao PH, Cigudosa JC, Ning Y, et al. Multicolo spectral karyotyping identifies new recurring breakpoints and translocations in multiple myeloma. Blood. 1998;92:1743-1748.

14. Avet-Loiseau H, Li JY, Facon T, et al. High incidence of translocations $t(11 ; 14)(q 13 ; q 32)$ and $\mathrm{t}(4 ; 14)$ (p16;q32) in patients with plasma cell malignancies. Cancer Res. 1998;58:5640-5645.

15. Proffitt J, Fenton J, Pratt G, Yates Z, Morgan G. Isolation and characterisation of recombination events involving immunoglobulin heavy chain switch regions in multiple myeloma using long distance vectorette PCR (LDV-PCR). Leukemia. 1999;13:1100-1107.

16. Barlogie B, Epstein J, Selvanayagam P, Alexanian R. Plasma cell myeloma-new biological insights and advances in therapy. Blood. 1989; 73:865-879.

17. Dreicer R, Alexanian R. Nonsecretory multiple myeloma. Am J Hematol. 1982;13:313-318.

18. Cavo M, Galieni P, Gobbi M, et al. Nonsecretory multiple myeloma: presenting findings, clinical course and prognosis. Acta Haematol. 1985;74: 27-30.

19. Rubio-Felix D, Giralt M, Giraldo MP, et al. Nonsecretory multiple myeloma. Cancer. 1987;59:18471852.

20. Garcia-Sanz R, Orfao A, Gonzalez M, et al. Primary plasma cell leukemia: clinical, immunophenotypic, DNA ploidy, and cytogenetic characteristics. Blood. 1999;93:1032-1037.

21. Blade J, Kyle RA. Nonsecretory myeloma, immunoglobulin D myeloma, and plasma cell leukemia. Hematol Oncol Clin North Am. 1999;13:12591272.

22. Van Dongen JJM, Adriaansen HJ, Hooijkaas H. Immunological marker analysis of cells in the various hematopoietic differentiation stages and their malignant counterparts. In: Ruiter DJ, Fleuren GJ, Warnaar SO, eds. Application of Monoclonal Antibodies in Tumor Pathology. Dordrecht: Martinus Nijhoff; 1987:87-116.

23. Van Dongen JJM, Wolvers-Tettero ILM. Analysis of immunoglobulin and T cell receptor genes. Part I: basic and technical aspects. Clin Chim Acta. 1991;198:1-91.

24. Beishuizen A, Verhoeven MA, Mol EJ, Breit TM, Wolvers-Tettero ILM, van Dongen JJM. Detection of immunoglobulin heavy-chain gene rearrangements by Southern blot analysis: recommendations for optimal results. Leukemia. 1993;7:20452053. 
25. Ravetch JV, Kirsch IR, Leder P. Evolutionary ap proach to the question of immunoglobulin heavy chain switching: evidence from cloned human and mouse genes. Proc Natl Acad Sci U S A. 1980;77:6734-6738.

26. Rabbitts TH, Forster A, Milstein CP. Human immunoglobulin heavy chain genes: evolutionary comparisons of $\mathrm{C}$ mu, $\mathrm{C}$ delta and $\mathrm{C}$ gamma genes and associated switch sequences. Nucleic Acids Res. 1981;9:4509-4524.

27. Krawinkel $\cup$, Rabbitts $T H$. Comparison of the hinge-coding segments in human immunoglobulin gamma heavy chain genes and the linkage of the gamma 2 and gamma 4 subclass genes. EMBO J. 1982;1:403-407.

28. Max EE, Battey J, Ney R, Kirsch IR, Leder P. Duplication and deletion in the human immunoglobulin epsilon genes. Cell. 1982;29:691-699.

29. Beishuizen A, Verhoeven MA, Mol EJ, van Dongen JJM. Detection of immunoglobulin kappa light-chain gene rearrangement patterns by Southern blot analysis. Leukemia. 1994;8:22282236.

30. Tümkaya T, Comans-Bitter WM, Verhoeven MA van Dongen JJM. Southern blot detection of immunoglobulin lambda light chain gene rearrangements for clonality studies. Leukemia. 1995;9: 2127-2132.

31. Szczepański T, Langerak AW, Wolvers-Tettero ILM, et al. Immunoglobulin and T cell receptor gene rearrangement patterns in acute lymphoblastic leukemia are less mature in adults than in children: implications for selection of PCR targets for detection of minimal residual disease. Leukemia. 1998;12:1081-1088.

32. Pongers-Willemse MJ, Seriu T, Stolz F, et al. Primers and protocols for standardized MRD detection in ALL using immunoglobulin and T cell receptor gene rearrangements and TAL1 deletions as PCR targets: report of the BIOMED-1 Concerted Action: investigation of minimal re- sidual disease in acute leukemia. Leukemia. 1999;13:110-118

33. Aubin J, Davi F, Nguyen-Salomon F, et al. Description of a novel FR1 IgH PCR strategy and its comparison with three other strategies for the detection of clonality in B cell malignancies. Leukemia. 1995;9:471-479.

34. Szczepański T, Pongers-Willemse MJ, Langerak $\mathrm{AW}$, et al. Ig heavy chain gene rearrangements in T-cell acute lymphoblastic leukemia exhibit predominant DH6-19 and DH7-27 gene usage, can result in complete V-D-J rearrangements, and are rare in T-cell receptor $\alpha \beta$ lineage. Blood. 1999;93: 4079-4085.

35. Beishuizen A, de Bruijn MAC, Pongers-Willemse $\mathrm{MJ}$, et al. Heterogeneity in junctional regions of immunoglobulin kappa deleting element rearrangements in B cell leukemias: a new molecular target for detection of minimal residual disease. Leukemia. 1997;11:2200-2207.

36. Klein U, Klein G, Ehlin-Henriksson B, Rajewsky $\mathrm{K}$, Kuppers R. Burkitt's lymphoma is a malig nancy of mature $B$ cells expressing somatically mutated $\mathrm{V}$ region genes. Mol Med. 1995;1:495505.

37. Langerak AW, Szczepański T, van der Burg M, Wolvers-Tettero ILM, van Dongen JJM. Heteroduplex PCR analysis of rearranged T cell receptor genes for clonality assessment in suspect $\mathrm{T}$ cell proliferations. Leukemia. 1997;11:2192-2199.

38. Cook GP, Tomlinson IM. The human immunoglobulin VH repertoire. Immunol Today. 1995;16: 237-242.

39. Sambrook J, Fritsch EF, Maniatis T. Molecular Cloning, a Laboratory Manual. Cold Spring Harbor, NY: Cold Spring Harbor Laboratory; 1989.

40. Corbett SJ, Tomlinson IM, Sonnhammer ELL, Buck D, Winter G. Sequence of the human immunoglobulin diversity (D) segment locus: a systematic analysis provides no evidence for the use of DIR segments, inverted D segments, "minor" D segments or D-D recombination. J Mol Biol. 1997;270:587-597.

41. Matsuda F, Ishii K, Bourvagnet $P$, et al. The complete nucleotide sequence of the human immunoglobulin heavy chain variable region locus. J Exp Med. 1998;188:2151-2162.

42. Van Dongen JJM, Wolvers-Tettero ILM. Analysis of immunoglobulin and T cell receptor genes. Part II: possibilities and limitations in the diagnosis and management of lymphoproliferative diseases and related disorders. Clin Chim Acta. 1991;198: 93-174.

43. Beishuizen A, Hählen K, Hagemeijer A, et al. Multiple rearranged immunoglobulin genes in childhood acute lymphoblastic leukemia of precursor B-cell origin. Leukemia. 1991;5:657-667.

44. Ghia P, ten Boekel E, Sanz E, de la Hera A, Rolink A, Melchers F. Ordering of human bone marrow $B$ lymphocyte precursors by single-cell polymerase chain reaction analyses of the rearrangement status of the immunoglobulin $\mathrm{H}$ and L chain gene loci. J Exp Med. 1996;184:22172229.

45. Sonoki $\mathrm{T}$, Matsuzaki $\mathrm{H}$, Satterwhite $\mathrm{E}$, et al. A plasma cell leukemia patient showing bialleic $14 q$ translocations: $\mathrm{t}(2 ; 14)$ and $\mathrm{t}(11 ; 14)$. Acta Haematol. 1999;101:197-201.

46. Kuipers J, Vaandrager JW, Weghuis DO, et al. Fluorescence in situ hybridization analysis shows the frequent occurrence of $14 \mathrm{q} 32.3$ rearrangements with involvement of immunoglobulin switch regions in myeloma cell lines. Cancer Genet Cytogenet. 1999;109:99-107.

47. Sakai A, Kawano MM, Tanabe O, Kuramoto A. A possible mechanism of inability of immunoglobulin heavy-chain production in Bence-Jones type myeloma cells. Int J Hematol. 1993;59:31-40.

48. Goossens T, Klein U, Kuppers R. Frequent occurrence of deletions and duplications during somatic hypermutation: implications for oncogene translocations and heavy chain disease. Proc Natl Acad Sci U S A. 1998:95:2463-2468. 